\author{
Matgorzata Turczyk \\ Uniwersytet Jagielloński \\ m.turczyk@uj.edu.pl
}

\title{
SZOK - jako kategoria w dyskusji o przemocy wobec dzieci
}

\section{Summary}

\section{SHOCK as a category in the discussion on violence against children}

SHOCK, as a recurring category that has been present for many years in the discourse on the right of the child/human to freedom from all forms of violence, becomes the focal point around which the considerations of this article are focused. The inspiration for the use of the shock category in education was the process of studying Anton Siemionowicz Makarenko's Pedagogical Poemate and the analysis of the educational system he created along practical directives for parenting and its pedagogical implications. In the text, a fundamental question is raised about how Makarenko used SHOCK as a tool in the educational process? The text presents an analysis of the SHOCK category based on the behavior of violence against a child and analyzes their pedagogical implications.

Słowa kluczowe: szok, dziecko, przemoc wobec dziecka, prawa człowieka, prawa dziecka, wychowanie

Keywords: shock, children, violence against the child, human rights, children rights, education

\section{Wstęp}

W ostatnich latach w społecznych mediach, w środowiskach politycznych i oświatowych przetacza się burzliwa dyskusja, dla której inspiracją stają się szeroko rozumiane zachowania agresywne występujące w społeczeństwie, a których ofiarami stają się dzieci. Bestialskie pobicia, często maleńkich dzieci, przez osoby najbliższe, akty wykorzystywania seksualnego i ekonomicznego, porzucenia, morderstwa, agresywne zachowania samych dzieci już od etapu przedszkolnego, przemoc rówieśnicza, przemoc w środowisku szkolnym. Tragiczne konsekwencje doświadczania przemocy przez dziecko rozlewają się w komunikatach społecznych i wywołują szok u każdego empatycznego człowieka. Stawiają także ważkie pytania o odpowiedzialność w rozumieniu pedagogicznym, prawny, stają się też narzędziem w dyskusji o kierunkach działań wychowawczych, społecznych i politycznych. W środowisku pedagogicznym kolejny raz przetacza się spór między zwolennikami nieopresyjnego, partycypacyjnego, demokratycznego wychowania a zwolennikami twardej dyscypliny, autorytaryzmu, kontroli a nawet przemocy w wychowaniu. Co szczególnie trudne, to dające się słyszeć głosy autorytetów naukowych mówiące o przemocy uza- 
sadnionej, rozumianej jako „słuszne uprawnienie/moralne, powinność dorosłych wobec dziecka" (Stawrowski 2016).

W środowisku polityczno-prawnym natomiast słychać głosy zwolenników zabezpieczania rzeczywistości społecznej/wychowawczej poprzez narzędzia i instytucje prawa pozytywnego i penalizacji przemocy wobec dziecka. $Z$ drugiej strony natomiast prezentowane są zupełnie odmienne koncepcje związane z reinterpretacjami idei absolutnej władzy rodzicielskiej, przymusu i znaczeniu „rózgi” w wychowaniu dziecka. Na arenie politycznej pojawiają się propozycje wycofania się z obszaru międzynarodowych standardów ochrony praw człowieka i przeciwdziałania przemocy.

Gdzieś u podstaw tych politycznych, normatywnych i pedagogicznych dyskusji o przymusie, prawie i swobodzie w procesie wychowania człowieka kryje się problem fundamentalny - problem zaufania w życiu społecznym. Profesor Maria Dudzikowa podkreśliła ten aspekt, pisząc o erozji kapitału społecznego w szkole w kulturze nieufności (Dudzikowa 2008). Rozpad kapitału, jakim jest społeczne zaufanie jest niezwykle niepokojącym zjawiskiem, które w konsekwencji generować może zachowania agresywne i przemocowe. „Kultura” nieufności społecznej, rodzinnej, szkolnej, zawodowej to odsłony tej samej rzeczywistości, u której podstaw leżą głęboko zakorzenione w świadomości wzorce kulturowe. I choć w skrajnej nieufności społecznej przyszło mu pracować z dziećmi i tworzyć system pedagogiczny, to jednak wbrew swoim czasom, Anton Siemionowicz Makarenko przeciwstawiał się temu zjawisku. W jego systemie wychowawczym mocno obecna jest wiara w człowieka, wiara wbrew kulturze nieufności. Założenia jego pedagogiki ściśle praktycznej, której cele pedagogiczne są jednocześnie celami politycznymi, określającymi stosunek pedagoga do rewolucji i toczącej się walki klasowej, mogą SZOKować współczesnego czytelnika. SZOK ten jednak staje się początkiem głębokiej osobowej i wychowawczej przemiany.

SZOK jest powracającym doświadczeniem, które towarzyszy mi w świadomym przyglądaniu się od wielu lat dyskursowi prawa dziecka/człowieka do wolności od wszelkich form przemocy. Warto zaznaczyć, iż ów ogląd z samej swojej rzeczy musi być wielowymiarowy. Kiedy poszukuję odpowiedniej kategorii do rozumienia tego fragmentu rzeczywistości społecznej, sam SZOK staje się soczewką, w której ogniskują się różne perspektyw, stanowiska naukowe, koncepcje aksjologiczne, a namysł pedagogiczny i psychologiczny, przeniknięty jest przez analizy socjologiczne, polityczne i prawne. SZOK zatem staje się dla mnie kategorią, która stwarza szansę na nowe odczytanie analizowanego problemu w kontekście pedagogicznej spuścizny Antona Makarenki.

SZOK należy do kategorii przemilczanych we współczesnej pedagogice, sam często rozumiany jest jedynie pejoratywnie. A jest to przecież kategorii mająca głębokie znaczenie wychowawcze. Kategorię tę odnalazłam, studiując dzieła Antona Makarenki, analizując stworzony przez niego system pedagogiczny i praktyczne dyrektywy postępowania wychowawczego. Stało się to bezpośrednią inspiracją do namysłu nad kategorią SZOKU w wychowaniu oraz nad jej pedagogicznymi implikacjami. 


\section{Kategorie w myśleniu o wychowaniu}

Niniejsze rozważania rozpocząć należy od analizy znaczenia samego terminu „kategoria”. Jak ją rozumieć i w jakiś sytuacjach pewien obiekt możemy określić mianem pedagogicznej kategorii badawczej?

Sam termin „kategoria” nauki społeczne zaczerpnęły z nauk matematycznych, przyrodniczych oraz z logiki filozoficznej. To właśnie Arystotelesowskie stałe sposoby orzekania o rzeczywistości uwzględniające jej podwójny aspekt metafizyczny i logiczny, tak szeroko omówione w kluczowym jego dziele zatytułowanym „Kategorie” zazwyczaj wyznaczają rozumienie tego terminu'. Odrębne rozumienie kategorii odnaleźć możemy w koncepcjach Kanta czy Heideggera. U Kanta kategorie rozumiane są jako aprioryczne, czyli pozadoświadczalne, zsubiektywizowane formy ludzkiego rozumu, które powstawać mogą także z subiektywnych przeżyć „,bytowania człowieka w świecie”. A zatem kategorie według Filozofa mogą być formami myślenia, za pomocą których człowiek może ogarniać intelektem i porządkować swoje doświadczenia. Dla Heideggara natomiast kategorie są formami projekcji, których twórcą jest człowiek przeżywający siebie w byciu i czasie (Gilson, Langan, Maurer 1979: 149 i nn.). Inaczej jeszcze kategorie rozumiał Hegel, który ich źródeł nie doszukiwał się w logice, ale wywodził je ze świata przyrody i nauk o duchu (Geistenswiessenschaften), co znacznie poszerzyło rozumienie kategorii i stać się może punktem wyjścia do analiz ich pedagogicznego wymiaru.

W literaturze pedagogicznej funkcjonuje wiele opisów i interpretacji terminu „,kategoria”. Joanna Rutkowiak, wykorzystując właśnie heglowskie rozumienie kategorii, analizuje pedagogiczne kategorie jako te, które „ukierunkowują myśl i organizują ją wokół pewnych kwestii, przy czym samą kwestię traktują jako dynamiczną" (Rutkowiak 1995: 25). Żeby przełamać tradycyjne myślenie o kategoriach Rutkowiak pisze dalej, że „(...) Kategorie nie są więc dogmatami, a określając ich kondycję mianem „pulsowania”, sygnalizuję podobieństwo do organizmu, dla istnienia którego znacząca jest dynamika, zmiana jakości i objętości, rytmu, (...) jako źródeł życiodajnego napięcia oraz braku ostrych granic znaczeniowych" (tamże). Ciekawe stanowisko dotyczące koncepcji kategorii w myśleniu pedagogicznym prezentuje Józef Górniewicz, dla którego kategorie to „(...) elementy rzeczywistości materialnej lub symbolicznej, stanowiące pewną funkcjonalną całość, będącą zestrojem elementów przynależnych do różnych obiektów rzeczywistości, także w jakiś sposób ustrukturowanych" (Górniewicz 1997: 7).

Problem, który bezpośrednio nasuwa się w tym miejscu można sformułować w postaci pytania o to, kiedy mamy prawo mówić o kategorii naukowej czy badawczej, a kiedy o pojęciach w nauce? Cytowany już wyżej J. Górniewicz twierdzi, że „dane pojęcia stają się kategoriami wówczas, gdy wnoszą do różnych nauk swoisty bagaż interpretacyjny, szerszy kontekst występowania $\mathrm{i}$ własną historię ugruntowaną w różnych dziedzinach nauki. Kategorie stanowią niejako konstrukcję, na której wspierają się analizy różnych

1 Zob. Stanford Encyclopedia of Philosophy, źródło: https://plato.stanford.edu/entries/categories/ (dostęp: 9.10.2017). 
fragmentów rzeczywistości społecznej. Konstrukcja ta dopełniana jest innymi, właściwymi dla danej dyscypliny naukowej pojęciami i interpretacjami” (Górniewicz 1997: 11). Zatem kiedy dane pojęcie ogniskuje w sobie punkty widzenia, konteksty interpretacyjne i koncepcje badawcze różnych dyscyplin nauki, kiedy staje się kontekstem analizowania problemów w wielu obszarach badawczych można nadać mu miano kategorii, która może stać się później przedmiotem interdyscyplinarnych badań naukowych.

\section{SZOK jako pedagogiczna kategoria badawcza}

Kiedy poszukuję rozumienia samego pojęcia SZOK, znajduję takie jego słownikowe określenia jak: „silna emocja, wstrząs psychiczny, wywołane jakimś gwałtownym przeżyciem” (Szymczak 1981: 420). Z medycznego punktu widzenia natomiast to „groźne dla życia zakłócenia pracy organizmu, wstrząs psychiczny” (Szymczak 1981: 420). Wyrazy pokrewne to razić, szokować, zaszokować, tajemniczością, niezwykłością. W słownikach pedagogicznych takie hasło nie występuje. SZOK to zawsze sytuacja związana z zaistnieniem pewnej ambiwalencji, kłopotliwości, koniecznością podjęcia refleksji w wymiarze aksjologicznym czy etycznym, moralnym.

Sama natomiast kategoria SZOKU analizowana w kontekście procesu wychowania staje się jądrem, wokół którego nadpisać można perspektywę interpretacyjną wielu dyscyplin nauki. Kiedy myślę o szoku w wychowaniu otwiera się także przestrzeń licznych interpretacji światopoglądowych czy politycznych, których bez wątpienia nie należy przemilczeć.

Kategorię SZOKU wykorzystuję do analizy zjawiska przemocy wobec dziecka. Staje się ona dla mnie perspektywą, która pozwala niejako spojrzeć z góry, dostrzec subtelne połączenia, barwy i wielości opisów tego fragmentu rzeczywistości społecznej. SZOK staje się kategorią, która przekracza możliwości poznania jednaj dyscypliny wiedzy. Kategoria SZOKU w wychowaniu sama w sobie stanowić może kategorię badawczą o charakterze interdyscyplinarnym. Możemy potraktować tę kategorię, za J. Rutkowiak, jako kategorię interdyscyplinarną, teoriotwórczą, poruszającą, pulsującą kategorię w myśleniu pedagogicznym.

Kategoria SZOKU w niniejszej refleksji będzie dla mnie narzędziem oglądu problematyki przemocy wobec dziecka w procesie wychowania. Ważnym kontekstem odniesienia, o jakim pisze J. Rutkowiak, staje się tu polityczność traktowana jako jedna z ,pulsujących kategorii”. Autorka rozważa ją jako zasadę myślenia o edukacji osadzonej w elementach konstytuujących byt społeczny. Wśród nich uwagę przykuwają takie kategorie jak: wolność/podporządkowanie jednostki, traktowanie społeczeństwa jako grup antagonistycznych/ kooperujących, traktowanie prawa jako prawa stanowionego, a aparatu państwa jako organizatora zezwalającego/ograniczającego wolność jednostki, wiedzy jako instrumentu sprawowania władzy, traktowanie ideologii jako systemu reprezentacji, oraz, co najważniejsze: wychowania jako przymuszanie/wyzwalanie (Rutkowiak 1995: 40).

Za pomocą kategorii SZOKU w wychowaniu zakreślam zatem mapę myślenia o przemocy wobec dzieci. Zjawisko przemocy wobec dziecka wymaga wyszukania do jej opisu 
kategorii na poziomie „meta” właściwej zarówno dla pedagogiki ogólnej, jak i dla refleksji prawnej. To właśnie kategoria SZOKU staje się niczym innym jak pryzmatem, w którym dochodzi do „załamania” owych perspektyw i dzięki któremu wydobyć się może nowa jakość widzenia, badania i opisywania zjawiska przemocy wobec dziecka.

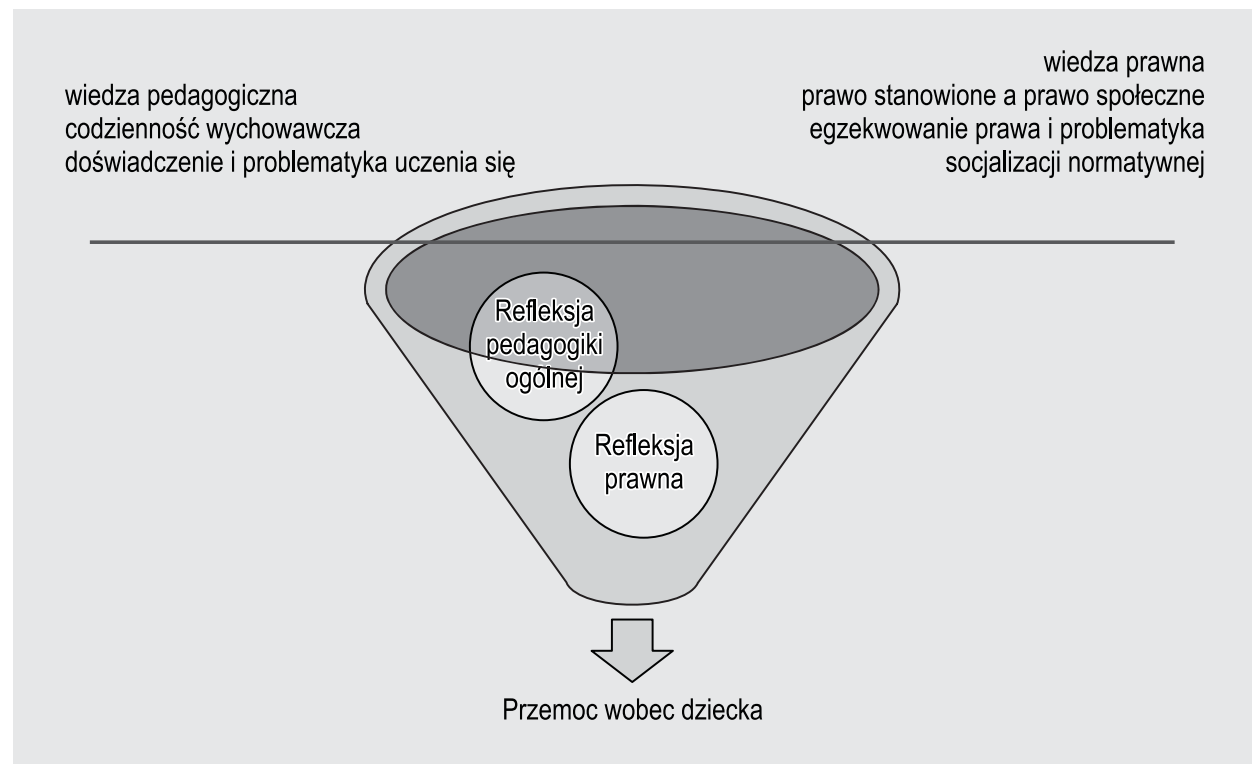

Rys. 1. SZOK jako metakategoria pedagogiczna

Źródło: opracowanie własne.

Domykając rozważania teoretyczne sięgnę do doświadczeń badawczych Doroty Pauluk, która przyjmuje, że możliwe i uprawnione jest tworzenie kategorii zgodnie z pojęciem dedukcyjnym (literatura, koncepcja badań), indukcyjnym (wyodrębnianie kategorii z materiatu źródlowego) lub też oba podejścia sa ze soba taczone. W podejściu dedukcyjnym po sformułowaniu problemu badawczego zaleca się teoretyczne osadzenie głównych kategorii i podkategorii, sformułowanie definicji, przykładów, zasad kodowanie na podstawie teorii. W podejściu indukcyjnym kategorie te sa ściśle powiązane $z$ treścia materiału źródlowego i nazywane w terminach jemu odpowiadajacych (Pauluk 2016: 147). Śmiało można powiedzieć, że kategoria SZOKU obecna jest w dyskursie praw dziecka, w literaturze pedagogicznej i prawnej, jednak jest ona do tej pory nieobecna, przemilczana i niewykorzystana do analizy tego dyskursu, co otwiera ciekawe perspektywy badawcze. 


\section{MAKARENKO i zaistnienie kategorii SZOKU w wychowaniu}

Doprowadzony do rozpaczy $i$ wściekłości tym wszystkim, co działo się $w$ ciagu poprzednich miesięcy, w zupetnej pasji, dotknięty do żywego, zamierzytem się i palnątem Zadorowa w twarz. Uderzytem mocno.

Zadorow zachwiat się i upadt na piec.

Uderzyłem go raz jeszcze, schwyciłem za kark, uniosłem i uderzyłem po raz trzeci. Najpewniej biłbym go jeszcze, ale on cicho pojękujac wyszeptat

- Przepraszam, Antonie Siemionowiczu...(Makarenko 1955: 22).

Powyższe słowa Antoniego Makarenki wywołując SZOK, stały się dla mnie inspiracją do refleksji i poszukiwań wychowawczych implikacji tej kategorii. W trakcie poznawania systemu wychowawczego stworzonego przez Makarenkę i podczas studiowania dzieł, jakie po sobie pozostawił SZOK wielokrotnie pojawiał się jako kategoria badawcza w moich analizach. Jednocześnie ten sam SZOK odczytywałam w reakcjach jego wychowanków i samego Makarenki. Makarenko oddziaływał SZOKIEM i poprzez SZOK. SZOK był dla Makarenki narzędziem w procesie wychowania i resocjalizacji dzieci i młodzieży. SZOK, w jego praktyce, nabiera cech swoistej metody wychowawczej, poprzez którą pedagog realizował zamierzone cele wychowawcze i socjalizacyjne.

Szokować mogą, we współczesnej świadomości pedagogicznych i psychologicznych konsekwencji stosowania przemocy w wychowaniu, opisy oddziaływań wychowawczych przedstawione przez Makarenkę w Poemacie pedagogicznym. Jednakże kiedy rozumieniem obejmę szeroki kontekst historyczny, ideologiczny i społeczno-politycznych czasu, w jakim przyszło Makarence tworzyć swój system, wówczas SZOK odnajduję jeszcze wyraźniej już tylko w przeżyciach i reakcjach dzieci, z którymi pracował Makarenko. W jego zachowaniu i wielkiej autorefleksji odnaleźć możemy niezwykłą wiarę w człowieka i szacunek do niego. Makarenko po zajściu z Zadorowem mówi do towarzysza Kaliny Iwanowicza w ten sposób:

Źle, bracie. Pierwszy raz w życiu uderzyłem człowieka" i dalej snuje własną refleksję „(...) tak, zbitem wychowanka. Przeżytem cała absurdalność pedagogiczna tego wydarzenia, całe bezprawie, jakiego się dopuściłem, zarazem jednak zdawałem sobie sprawę, że czystość moich poczynań pedagogicznych - to w porównaniu z zadaniem, jakie miałem do spetnienia, rzecz mniejszej wagi (Makarenko 1955: 25).

Co istotne, zachowanie Makarenki wobec wychowanka nie było powszechnie akceptowane. Spotkało się ono z ostrą krytyką pracownicy kolonii Lidi Pietrowny.

Kiedy jednak to samo wydarzenie przeanalizujemy z punktu widzenia wychowanków kolonii to w ich doświadczeniu $\mathrm{z}$ łatwością odnajdziemy opisywaną kategorię. SZOK był przeżyciem, które towarzyszyło nie tylko Zadorowi, ale i jego współtowarzyszom. SZOK, który z czasem przemienił się w zachwyt, pozwolił zrealizować praktyczne cele wychowawcze założone przez Makarenkę.

Jekatierina Grigorjewna w dialogu z Makarenką twierdzi, że chłopcy opowiadaja o waszym wyczynie z zachwytem. Gotowi sa nawet zakochać się w was, Zadorow przede 
wszystkim...(Makarenko 1955: 26). Makarenko twierdzi, że wychowankowie $w$ tej całej historii nie widza bicia, widza tylko gniew, wybuch ludzkiego gniewu (...). Mówi dalej: Uciektem się do podstępku, który byt niebezpieczny dla mnie, ale byt ludzki, nie formalny. (...) Sprawa jest bardziej skomplikowana. Widza (wychowankowie - wtrącenie własne), że pracujemy dla nich. Są przecież jednak ludźmi. To ważna okoliczność (Makarenko 1955: 26).

Tę wiarę w człowieka i wyjaśnianie motywów i konsekwencji jego działań Makarenko opiera właśnie na sferze społecznej i na wierze w wielką siłę drzemiącą w ludziach i możliwości dostrzeżenia w nich dobra. Makarenko wielokrotnie podkreśla i rozumie, zgodnie z dominującą wówczas ideologią, społeczne determinanty ludzkich zachowań (Lewin 1960: 137). Podobnie rozumie i wyjaśnia potrzeby swoich wychowanków, które określa jako sitę życiowa, która można kierować $i$ wychowywać, sens jego działan pedagogicznych i stosunek do drugiego człowieka polega na tym, by dostrzegać w każdej jednostce wielkie możliwości twórcze nigdy się nad nim nie roztkliwiać i nie zmniejszać wobec niego wymagań (Makarenko 1955: 123). A jednak prowadzić go odważnie i odpowiedzialnie do radości dnia jutrzejszego (Lewin 1960: 237).

Bardzo mocno widać w całej koncepcji Makarenki wpływ kryzysu ahistorycznych koncepcji człowieka końca XIX i początku XX wieku. Więcej światła na przestrzeń pedagogicznej rzeczywistości i dylematów pedagogicznych Makarenki rzuca Aleksander Lewin, analizując historyczno-ideologiczne uwarunkowania pracy pedagogicznej Makarenki (Lewin 1960: 123). I choć sama przemoc w wychowaniu nie była wówczas specjalnie szokująca społecznie o tyle Makarenko, wykorzystując kategorię SZOKu w swojej pracy wychowawczej, zasadniczo sprzeciwiał się stosowaniu przemocy: Musze jednak stwierdzić, że ani przez chwilę nie uważatem przemocy za jakiś uniwersalny środek pedagogiczny. Zajście z Zadorowem kosztowato mnie więcej niż samego Zadorowa (Makarenko 1955: 25). Makarenko ostro odcina się od przemocy jako metody wychowawczej, a jednak dopuścił ją jako podstęp w swoim postępowaniu z wychowankami, wciąż poszukując takiej metody, która ,,daje każdej jednostce możność rozwijania swoich wtaściwości, zachowania własnej indywidualności" (cyt. za Makarenko, [w:] Lewin 1960: 228).

Moje doświadczenie SZOKU, stając się rozumiejące, pozwala wyraźniej zobaczyć, w jaki sposób za pomocą SZOKU oddziaływał sam Makarenko i jakie efekty wychowawcze przynosiło jego działanie. Pozwala też odczytać ogromny trud, z jakim przeżywał on swoją misję pedagogiczną, ogromne zmaganie oraz głęboką autorefleksję, jaka mu w tym procesie towarzyszyła. Sam Makarenko pisze, że każda reakcja wychowawcza jest wymordowana - powstająca w trudzie samoświadomości i odpowiedzialności.

Powyższe rozważania o znaczeniu kategorii SZOKU w wychowaniu u Makarenki obrazować może poniższy rysunek: 


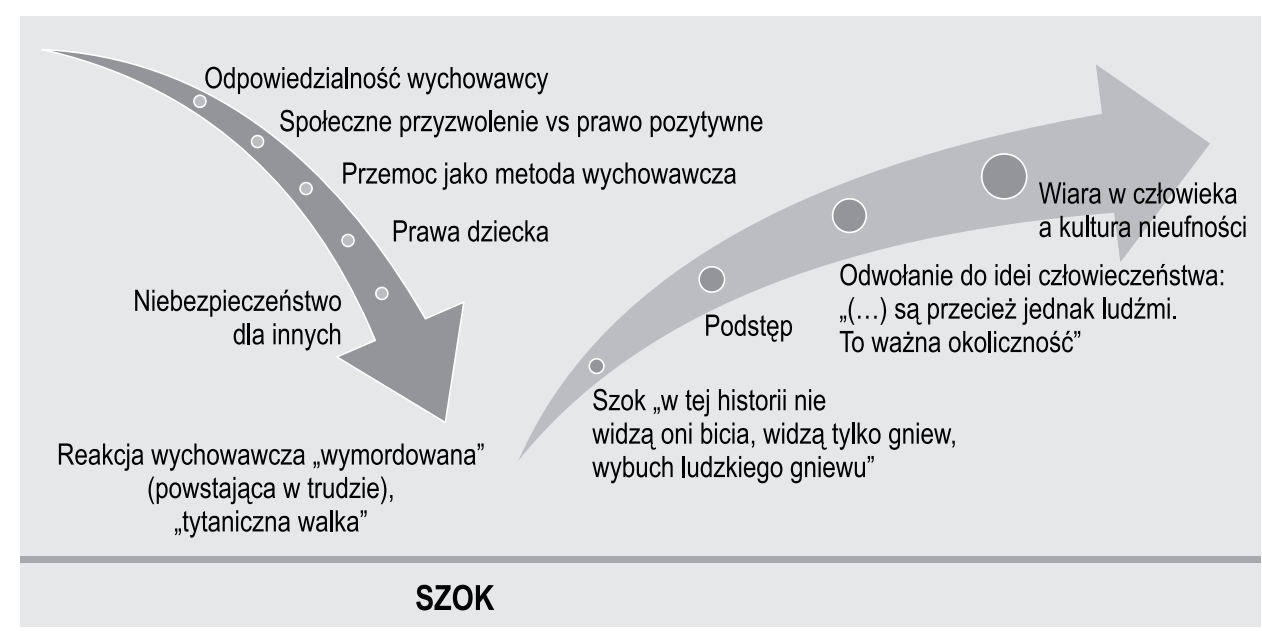

Rys. 2. Wychowanie poprzez SZOK u Makarenki

Źródło: opracowanie własne.

\section{Zakończenie}

W polu poznawczym kategorii praw dziecka do wolności od wszelkich form przemocy przenikają się obszary wiedzy pedagogicznej, filozoficznej, prawnej, psychologicznej, socjologicznej, medycznej czy nawet teologicznej. Samo jednak badanie owej kategorii z perspektywy jednej tylko dziedziny nauki nie pozwala na dostrzeżenie wewnętrznej dynamiki pojęcia i zubaża proces wyjaśniania określonego fragmentu rzeczywistości społecznej jaką są prawa dziecka. Nie pozwala tym samym na dookreślenie rozumienia owej kategorii w znacznym stopniu determinującej współczesne rozumienie dziecka. W tej sytuacji na gruncie pedagogiki, pozostającej w ścisłym związku z wieloma naukami pomocniczymi, powinna pojawić się próba włączenia nowej kategorii badawczej pozwalającej na odsłonięcie szerszego kontekstu problematyki przemocy wobec dziecka w celu budowania teorii naukowej. SZOK jest kategorią, która przekracza możliwości poznania jednaj dyscypliny wiedzy, odsłania możliwość rozumienia przedmiotowego zagadnienia nie tylko w aspekcie wertykalnej refleksji międzydyscyplinarnej, ale także w jej wymiarze horyzontalnym - międzyosobowym. SZOK rozumiany jako działanie zaskakujące i niezgodne z „oczekiwaniem” w danej sytuacji, w kontekście określonych zachowań prezentowanych przez wychowawcę (Makarenkę) w celach wywołania go jako bodźca zapoczątkowującego refleksje u wychowanka lub też podnoszącego pozycję wychowawcy w kontekście norm wyznawanych przez wychowanków, staje się czynnikiem zmiany indywidualnej, a może częściowo również i społecznej. W tym ujęciu kategoria SZOKU analizowana może być w kontekście psychologicznego efektu lub w kontekście filozoficznej refleksji nad jego wpływem na ludzkie życie. 
Wspaniale widać to na podstawie analizy dzieła Antona Makarenki Poemat pedagogiczny, gdzie poprzez SZOK dochodzą do głosu narracje pedagogicznego trudu wychowania i bycia wychowywanym. Narracje, które jednoznacznie odcinają się od stosowania przemocy w wychowaniu, nie aprobując tej formy w relacjach międzyludzkich. Choć jeszcze raz podkreślić trzeba, że sama przemoc $\mathrm{w}$ wychowaniu zjawiskiem szokującym w czasach, w jakich tworzył Makarenko nie była. SZOK analizowany jako kategoria interdyscyplinarna, teoriotwórcza, poruszająca kategoria pedagogiczna jednocześnie staje się wyzwaniem i głosem w kierunku ochrony prawa dziecka do wolności od wszelkich form przemocy. Podkreślić należy, że ważną rolę w tym dyskursie zaznacza postać Antona Makarenki, którego dorobek pedagogiczny wywarł znaczny wpływ na rozwój również polskiej myśli pedagogicznej, jednakże nie był do tej pory analizowany pod kątem, opartego na głębokiej refleksji pedagogicznej, odcięcia się od zjawiska przemocy w wychowaniu.

\section{Literatura}

Gilson E., Langan T., Maurer A.A. (1979), Historia filozofii wspótczesnej: od Hegla do czasów najnowszych; przel. Chwedeńczuk B., Zalewski B., Warszawa, Wydawnictwo PAX.

Górniewicz J. (1997), Kategorie pedagogiczne. Olsztyn, Wydawnictwo WSP.

Kupisiewicz Cz., Kupisiewicz M. (2009), Słownik pedagogiczny. Warszawa, Wydawnictwo Naukowe PWN.

Lewartowska-Zychowicz M. (2003), Hasło: kategoria. W: T. Pilch (red.), Encyklopedia pedagogiczna XXI wieku, T. II. Warszawa, Wydawnictwo Akademickie „Żak”.

Lewin A. (1960), Makarenko. Konfrontacje pedagogiczne. Warszawa, Państwowe Zakłady Wydawnictw Szkolnych.

Makarenko A. (1955), Poemat pedagogiczny. Warszawa, Państwowe Zakłady Wydawnictw Szkolnych.

Milerski B., Śliwerski B. (2000), Pedagogika. Leksykon PWN. Warszawa, Wydawnictwo Naukowe PWN.

Pauluk D. (2016), Ukryte programy uniwersyteckiej edukacji i ich rezultaty. Doświadczenia studentów pedagogiki. Kraków, Wydawnictwo UJ.

Szymczak M. (red.) (1981), Słownik Języka Polskiego. Warszawa.

Stawrowski Z. (2016), Klaps to obowiązek rodziców, „Rzeczypospolita” 15.09.2016, http://www. rp.pl/Plus-Minus/309159952-Zbigniew-Stawrowski-Klaps-to-obowiazek-rodzicow.html (dostęp: 10.10.2016). 